\title{
Constraining recent Shiveluch volcano eruptions (Kamchatka, Russia) by means of dendrochronology
}

\author{
O. Solomina ${ }^{1}$, I. Pavlova ${ }^{1}$, A. Curtis ${ }^{2}$, G. Jacoby ${ }^{2}$, V. Ponomareva ${ }^{3}$, and M. Pevzner ${ }^{4}$ \\ ${ }^{1}$ Institute of Geography RAS, Staromonetny-29,119017, Moscow, Russia \\ ${ }^{2}$ Lamont-Doherty Earth Observatory, Palisades, NY, USA \\ ${ }^{3}$ Institute of Volcanology and Seismology FED RAS, Piip Blvd. 9, Petropavlovsk-Kamchatsky, 683006, Russia \\ ${ }^{4}$ Geological Institute RAS, Pyzhevsky Per. 7, 119017, Moscow, Russia
}

Received: 5 December 2007 - Revised: 21 August 2008 - Accepted: 24 August 2008 - Published: 15 October 2008

\begin{abstract}
Shiveluch (N 56 $38^{\prime}$, E $161^{\circ} 19^{\prime}$; elevation: active dome $\sim 2500 \mathrm{~m}$, summit of Old Shiveluch $3283 \mathrm{~m}$ ) is one of the most active volcanoes in Kamchatka. The eruptions of Shiveluch commonly result in major environmental damage caused by debris avalanches, hot pyroclastic flows, tephra falls and lahars. Constraining these events in time and space is important for the understanding and prediction of these natural hazards. The last major eruption of Shiveluch occurred in 2005; earlier ones, dated by instrumental, historical, ${ }^{14} \mathrm{C}$ and tephrochronological methods, occurred in the last millennium around $\mathrm{AD} 1030,1430,1650,1739$, 1790-1810, 1854, 1879-1883, 1897-1898, 1905, 1927$1929,1944-1950$, and 1964. A lava dome has been growing in the 1964 crater since 1980 , occasionally producing tephra falls and pyroclastic flows. Several Shiveluch eruptions ( $\sim$ AD 1050, 1650, 1854, 1964) may have been climatically effective and are probably recorded in the Greenland ice cores.
\end{abstract}

Previously, most dates for eruptions before AD 1854 were obtained by tephrochronology and constrained by radiocarbon dating with an accuracy of several decades or centuries. In this paper we report tree-ring dates for a recent pyroclastic flow in Baidarnaia valley. Though the wood buried in these deposits is carbonized, fragile and poorly preserved, we were able to measure ring-width using standard tree-ring equipment or photographs and to cross-date these samples against the regional Kamchatka larch ring-width chronology. The dates of the outer rings indicate the date of the eruptions. In the Baidarnaia valley the eruption occurred shortly after AD 1756, but not later than AD 1758. This date coincides with the decrease of ring-width in trees growing near Shiveluch volcano in 1758-1763 in comparison with

Correspondence to: O. Solomina

(olgasolomina@yandex.ru) the control "non-volcanic" chronology. The pyroclastic flow in Kamenskaia valley, although similar in appearance to the one in Baidarnaia valley, definitively yielded a different age. Due to the age limit of the reference chronology (AD 16322005) and its short overlap with the sample chronology in Kamenskaia valley the dates of these deposits are very preliminary. The deposits probably date back to approximately AD 1649 or a few years later. This date is in close agreement with the previously obtained radiocarbon date of these sediments to AD 1641(1652)1663. Our data agree well with the tephrochronological findings, and further constrain the chronology of volcanic events in this remote area.

\section{Introduction}

Tree rings can record the dates of local volcanic eruptions if the trees are directly damaged by fire or buried by tephra (Yamaguchi, 1983, 1985, 1993; Yamaguchi and Hoblitt, 1995). Climatically effective eruptions can be detected in ring-width and density (Briffa et al., 1998; Jones et al., 1995; Jacoby et al., 1999), frost ring (LaMarche and Hirschboeck, 1984), and light ring (Filion et al., 1986) series because such eruptions lead to abrupt drops of summer temperature and hence to changes in rings properties. Detailed reconstruction of volcanic activity is also important for understanding temporal patterns, predicting the volcano's future activity and mitigating natural hazard effects. In this paper, we consider the first ever tree-ring dates obtained for the eruptions of Shiveluch volcano - one of the most active and unpredictable explosive volcanoes in Kamchatka.

Shiveluch's eruptive history during the Holocene includes several important events that are rather well known (Braitseva et al., 1997a; Ponomareva et al., 1998; 2007). Most

Published by Copernicus Publications on behalf of the European Geosciences Union. 


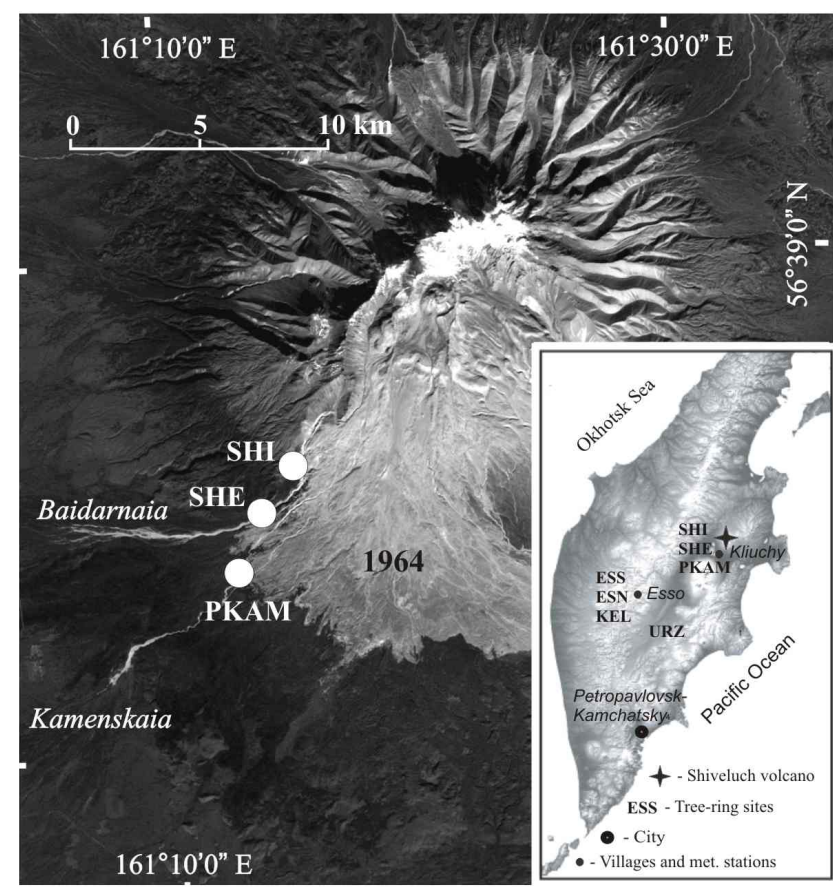

Fig. 1. Map of Kamchatka and Shiveluch volcano. Tree-ring site locations.

dates for the pre-AD 1854 eruptions were obtained by tephrochronology and constrained by radiocarbon dating with an accuracy of several decades or centuries. A treering approach could, however, provide more accurate dating for some of these eruptions. Larch and spruce species, previously used successfully for tree-ring climatic reconstructions in Kamchatka (e.g. Gostev et al., 1996; Furuta et al., 2002; Solomina et al., 2007), grow on the slopes and foothills of Shiveluch volcano. These same tree species buried by various volcanic deposits during the eruptions can now be found in outcrops along the river valleys.

In this paper, we provide tree-ring dates of wood buried in the pyroclastic flow of Shiveluch volcano to (i) constrain the previously obtained ${ }^{14} \mathrm{C}$ dates, (ii) assess unverified anecdotal evidences, and (iii) identify an unknown eruption. We analyze (iv) the potential volcanic signal of Shiveluch in the larch and spruce chronologies from the living trees growing on the slopes of this volcano and (v) compare them with the chronologies from the non-volcanic, undisturbed areas of Kamchatka.

\section{Recent eruptions from Shiveluch volcano}

Shiveluch volcano (also spelled sometimes as Sheveluch) is located in the northern part of the Kamchatka Peninsula (N 56 $38^{\prime}$, E $161^{\circ} 19^{\prime}$ ) (Fig. 1), which hosts about 30 active and 300 extinct volcanoes. The elevation of its summit (ex-

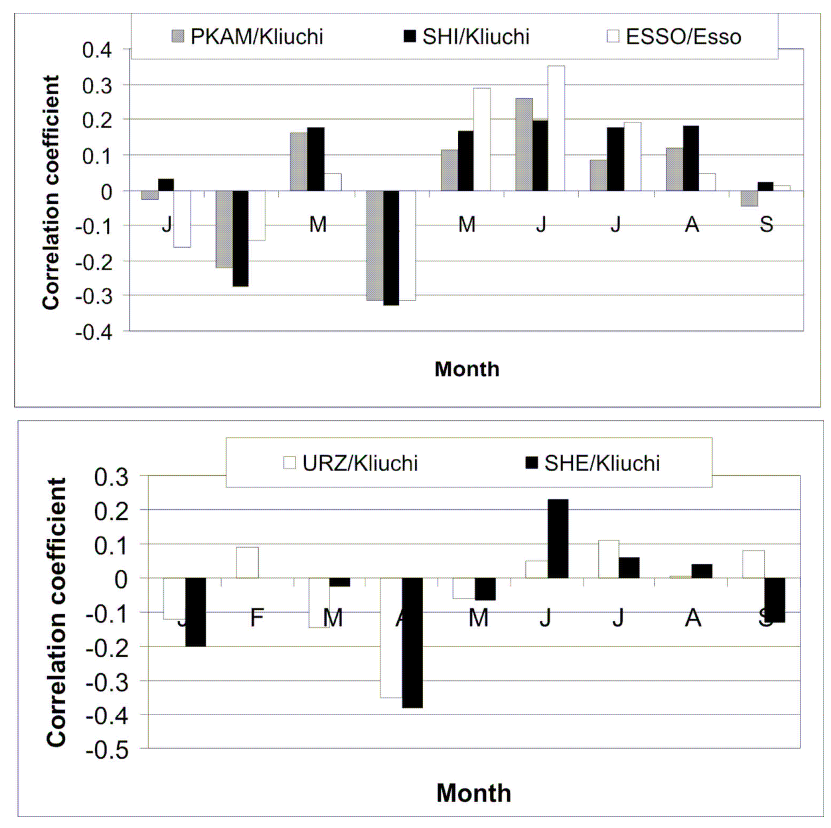

Fig. 2. Coefficients of correlation of larch (a) and spruce (b) ringwidth standard chronologies with monthly temperatures measured at Esso and Kliuchi meteorological stations.

tinct Old Shiveluch volcano) is $3283 \mathrm{~m}$, and that of the active lava dome $\sim 2500 \mathrm{~m}$. Shiveluch is known as one of the most active explosive volcanoes of Kamchatka (Melekestsev et al., 1991; Ponomareva et al., 2007). Its eruptive deposits include tephra falls, pyroclastic flows, debris avalanches, and debris flows (lahars). The Holocene ignimbrites and debris avalanche deposits occur primarily to the south of the volcano (see Fig. 1). The tephra falls disperse in all directions depending on the prevailing wind at the time of eruption. Lahar deposits descend down all the radial valleys and form fans around the volcano. During eruption, the hot pyroclastic material not only buries the landscape under a thick layer of pumice, but hits and burns the trees and other vegetation, creating many charcoal-rich ignimbrites at Shiveluch.

Written records (Table 1) of Shiveluch volcanic activity date back to 1739 and report on eruptions in 1739 , 1790 (1793), and between 1790-1810, but this information lacks certainty (Gorshkov and Dubik, 1970). More reliable records begin in 1854 when a large eruption accompanied by voluminous tephra fall was recorded (Ditmar, 1890). Moderate eruptions occurred in 1879-1883, 18971898, 1905, 1927-1929 and 1944-1950 (Gorshkov and Dubik, 1970; Meniailov, 1955). A large plinian eruption of Shiveluch took place in 1964 . It began with a large debris avalanche (see Fig. 1) and a minor phreatic explosion (Belousov, 1995) followed by a powerful plinian eruption which produced tephra fall and pyroclastic flow deposits (Gorshkov and Dubik, 1970). A lava dome has been growing in the 1964 crater since 1980, occasionally producing 
Table 1. Recent eruptions from Shiveluch dated by different methods.

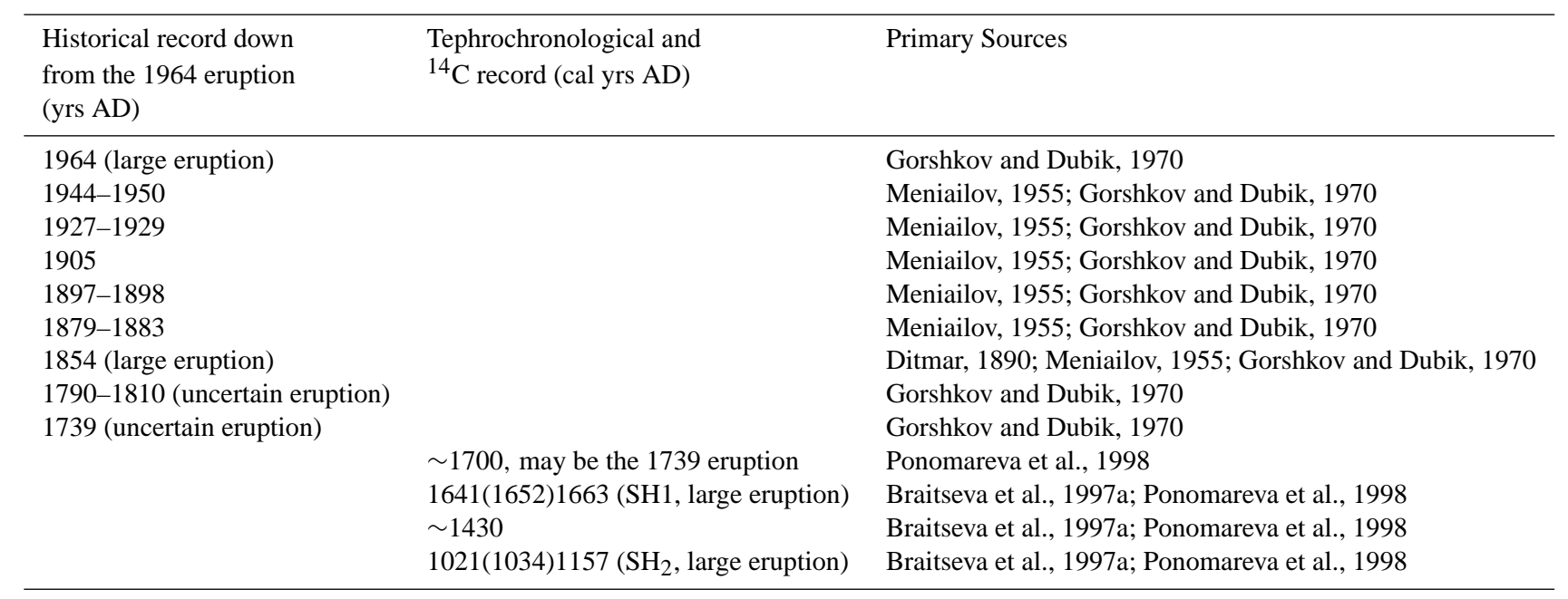

small block-and-ash flows, landslides, and minor ashfalls. The most recent strong eruption associated with the dome activity took place in 2005 (http://www.kscnet.ru/ivs/kvert/ volcanoes/Sheveluch/index_eng.html).

Large prehistoric eruptions from Shiveluch have been reconstructed by tephrochronological methods and dated with the help of conventional radiocarbon dating on bulk paleosols and charred and non-charred wood found in the ignimbrites (Ponomareva et al., 1998, 2007). The calibrated ages of the most recent prehistoric eruptions suggest that they occurred AD 1021(1034)1157 (eruption coded $\mathrm{SH}_{2}$ ), around AD 1430, and 1641(1652)1663 ( $\left.\mathrm{SH}_{1}\right)$ (Braitseva et al., 1997a; Ponomareva et al., 1998). All these eruptions produced pyroclastic flows (Ponomareva et al., 2007). Between the $\mathrm{SH}_{1}$ and historically recorded $\mathrm{AD} 1854$ eruption at least one more moderate eruption occurred that produced an ash fall and a pyroclastic flow to the south of the volcano. This eruption was not dated but the thickness of sandy loam between its tephra and the $\mathrm{SH}_{1}$ layer suggests an interval of more than 50 years (Ponomareva et al., 1998). This eruption could therefore be either the last prehistoric event or the first event described in written records with some uncertainty in 1739 or 1790-1810 (Gorshkov and Dubik, 1970). It could also easily be an undocumented 18th century eruption because the vicinity of the volcano was sparsely populated at that time. A number of recent eruptions from Shiveluch ( $\sim$ AD 1050 , ca. 1650, 1854, 1964) may have been climatically effective and are probably recorded in the Greenland ice cores (Braitseva et al., 1997a; Zielinski et al., 1994).

\section{Dated tree-ring data}

In order to date subfossil tree-ring samples, we sampled and dated living trees and assembled data from previous sam- pling and studies. Two larch stands (SHI, PKAM) and one spruce (SHE) site on the slopes of Shiveluch volcano were sampled in 2003 and 2006 (Table 2). These trees are located in the zone of potential influence of the volcanic eruptions (see Fig. 1) and many of these trees have survived multiple eruptions. The ESSO reference chronology used for the detection of volcanic signals was assembled from three local chronologies, ESN, ESS, and KEL, (KEL constructed by S. Shiyatov, ITRDB), located in the non-volcanic area of Kamchatka (see Table 2 and Fig. 1). URZ is a local spruce chronology from the forest in the Kamchatka river valley not far from the Shiveluch sites, but outside the direct influence of volcanic activity.

We used standard dendroclimatological procedures (Cook and Kairiukstis, 1990) including COFECHA-based crossdating and quality control (Holmes, 1983) to develop the chronologies. ARSTAN (Cook, 1985) was used for a conservative detrending and subsequent chronology development.

Several authors (Gostev et al., 1996; Solomina et al., 2007) reported that larch ring-width chronologies in Kamchatka are temperature sensitive and have significant correlations with May and June temperatures. Both "volcanic" and "nonvolcanic" larch chronologies show this very similar reaction to climatic factors: the lack of response to precipitation (insignificant coefficients of correlation), a positive reaction to May and early summer temperature signals, and negative correlation with April temperature (Fig. 2a). The "volcanic" chronologies from the Shiveluch area display the same climatic signal. The spruce ring-widths react negatively to the April temperature, although the positive reaction to the temperature in the warm period is less pronounced (Fig. 2b). However what is important in the context of this paper is that the spruce chronologies - both the reference URZ chronology and the one from Shiveluch area (SHE) show a rather 
Table 2. Chronologies used in this study. KEL chronology constructed by S. Shiyatov, ITRDB.

\begin{tabular}{|c|c|c|c|c|c|c|c|c|c|}
\hline Sites & Location & Species & $\mathrm{N}$ & $\mathrm{E}$ & Altitude, m & Years & $\begin{array}{l}\mathrm{N} \text { of dated } \\
\text { series }\end{array}$ & $\begin{array}{l}\text { Series } \\
\text { intercor- } \\
\text { relation }\end{array}$ & $\begin{array}{l}\text { Average } \\
\text { mean } \\
\text { sensitivity }\end{array}$ \\
\hline SHI & $\begin{array}{l}\text { Baidarnaia valley, } \\
\text { Shiveluch volcano }\end{array}$ & larch & 5633359 & 16110406 & 600 & $1695-2003$ & 20 & .745 & .386 \\
\hline SHE & $\begin{array}{l}\text { Baidarnaia valley, } \\
\text { Shiveluch volcano }\end{array}$ & spruce & 5633359 & 16110406 & 450 & 1793-2003 & 18 & .684 & .228 \\
\hline PKAM & $\begin{array}{l}\text { Pravaia Kamenskaia valley, } \\
\text { Shiveluch volcano }\end{array}$ & larch & 563336 & 1611041 & 60 & 1669-2005 & 20 & .745 & .395 \\
\hline URZ & Urz valley & spruce & 550760 & 1590685 & 100 & 1700-2003 & 37 & .629 & .233 \\
\hline ESS & Esso village & larch & 5554 & 15848 & $500-700$ & 1632-1993 & 13 & .752 & .317 \\
\hline ESN & Esso village & larch & 5554 & 15848 & $500-700$ & 1704-1997 & 16 & .719 & .317 \\
\hline KEL & Esso village & larch & 5554 & 15848 & 900 & 1690-1984 & 25 & .740 & .358 \\
\hline
\end{tabular}

Table 3. Coefficients of correlation of larch (ESSO, SHI, PKAM) and spruce (URZ and SHE) ring-width chronologies (all except PKAM/URZ are significant at $95 \%$ confidence level).

\begin{tabular}{llllll}
\hline & ESSO & & SHI & PKAM & URZ \\
\hline ESSO & 1 & & & & \\
SHI & 0.58 & 1 & & \\
PKAM & 0.45 & 0.78 & 1 & \\
URZ & 0.39 & 0.20 & 0.16 & 1 \\
SHE & 0.27 & 0.26 & 0.40 & 0.30 \\
\hline
\end{tabular}

similar reaction to climatic variations (see Fig. 5a, b). Although the spruce chronologies are less well replicated and are generally are less sensitive to climatic variations, the spruce samples cross-date well and we use spruce chronologies in this paper as a supplementary source of information.

There is agreement between the spruce and larch ringwidth chronologies (Table 3), however these two species cannot be combined into a single chronology due to somewhat different climatic responses. Therefore we also consider separately the two spruce (SHE, URZ) and three larch (PKAM, SHI, ESSO) chronologies both from "volcanic" and "nonvolcanic" areas. We use the larch chronologies from the year 1632 although it is not well-replicated before 1700 . We cut the spruce chronologies at 1800 and exclude their less wellreplicated portions.

We analyze the cases when the "volcanic" curves of the Shiveluch slope chronologies (larch: SHI, PKAM; spruce: SHE) deviate from "climatic" curves, i.e. when the minima are not repeated by the "non-volcanic" reference chronologies (larch: ESSO; spruce: URZ). We presume that these unrepeated minima are related to volcanic influence, however they certainly can also result from other factors, such as local climatic variability and insect outbreaks. These data can be used as an additional source of information to constrain the dates of volcanic events if wood samples buried in the volcanic deposits are cross-dated.

\section{Sampling of subfossil wood}

The calibrated dates of the last millennium eruptions of Shiveluch show very broad time intervals. To further constrain the dates of the volcanic events we collected wood and charcoal samples buried in various ignimbrite units of Shiveluch volcano in the Baidarnaia and Kamenskaia valleys, which both drain to the southwest. Deposits exposed are younger than $\sim 3 \mathrm{ka}$ in the Baidarnai valley and younger than $1.5 \mathrm{ka}$ in the Kamenskaia valley (Ponomareva et al., 2007).

While the outer-ring ages provide the year of eruption and death of the tree, the year of the pith is an important indicator of the date of surface colonization and can be related to the previous volcanic event. In Kamchatka, marginal parts of fresh volcanic deposits may be colonized by wood vegetation within a few years (Grishin et al., 2000). The central parts of the pyroclastic fans, however, may require several decades for colonization, depending largely on the deposit characteristics. Due to this difference, the oldest date on the pith provides an upper age limit for the underlying pfu but may be somewhat younger than the date of its emplacement.

\section{Results}

In Table 4 we show a section of COFECHA output, where we included all dated wood fragments from Shiveluch forefields together with the longest samples from the Kamchatka regional larch ring-width chronology, which was used for the cross-dating procedure. Most charcoal samples are rather short and they are almost at the edge of reliable dating. The length of the reference chronology (1632-2005) is enough for the dating of the Baidarnaya samples, but overlaps with the Kamenskaya samples only by 14 years. We are aware of these limitations of our dating and discuss it below separately for the two sets of data. 
Table 4. PART 5: CORRELATION OF SERIES BY SEGMENTS: 00:04 Wed 09 Jul 2008 Page 5.

Correlations of 50-year dated segments, lagged 25 years

Flags: $A=$ correlation under .3281 but highest as dated; $B=$ correlation higher at other than dated position.

\begin{tabular}{|c|c|c|c|c|c|c|c|c|c|c|c|c|c|c|c|c|c|c|c|}
\hline Seq & Series & Time_span & $\begin{array}{l}1575 \\
1624\end{array}$ & $\begin{array}{l}1600 \\
1649\end{array}$ & $\begin{array}{l}1625 \\
1674\end{array}$ & $\begin{array}{l}1650 \\
1699\end{array}$ & $\begin{array}{l}1675 \\
1724\end{array}$ & $\begin{array}{l}1700 \\
1749\end{array}$ & $\begin{array}{l}1725 \\
1774\end{array}$ & $\begin{array}{l}1750 \\
1799\end{array}$ & $\begin{array}{l}1775 \\
1824\end{array}$ & $\begin{array}{l}1800 \\
1849\end{array}$ & $\begin{array}{l}1825 \\
1874\end{array}$ & $\begin{array}{l}1850 \\
1899\end{array}$ & $\begin{array}{l}1875 \\
1924\end{array}$ & $\begin{array}{l}1900 \\
1949\end{array}$ & $\begin{array}{l}1925 \\
1974\end{array}$ & $\begin{array}{l}1950 \\
1999\end{array}$ & $\begin{array}{l}1975 \\
2024\end{array}$ \\
\hline 11 & pkam11a & 16331663 & & & .54 & & & & & & & & & & & & & & \\
\hline 12 & pkam11a & 16902006 & & & & & .62 & .80 & .81 & .77 & .75 & .58 & .60 & .75 & .70 & .74 & .69 & .69 & .67 \\
\hline 13 & pkam11b & 17062006 & & & & & & .83 & .80 & .47 & .52 & .58 & .62 & .74 & .67 & .63 & .65 & .69 & .71 \\
\hline 15 & PKAM12b & 17212005 & & & & & & .33 & .38 & .75 & .74 & .74 & .79 & .77 & .62 & .61 & .63 & .77 & .79 \\
\hline 21 & pkam15b & 16692006 & & & & .66 & .69 & .76 & .56 & .53 & .70 & .69 & .75 & .77 & .78 & .83 & .79 & .69 & .72 \\
\hline 22 & KEL021 & 17021984 & & & & & & .57 & .75 & .61 & .49 & .39 & .63 & .82 & .75 & .61 & .67 & .72 & \\
\hline 23 & KEL022 & 17141984 & & & & & & .57 & .74 & .76 & .62 & .54 & .65 & .75 & .75 & .60 & .52 & .62 & \\
\hline 32 & KEL091 & 17061983 & & & & & & .86 & .84 & .75 & .68 & .56 & .65 & .70 & .67 & .83 & .84 & .84 & \\
\hline 36 & KEL131 & 17201983 & & & & & & .81 & .82 & .80 & .79 & .74 & .81 & .69 & .59 & .84 & .62 & .66 & \\
\hline 37 & KEL132 & 16981983 & & & & & .78 & .79 & .76 & .77 & .79 & .64 & .72 & .76 & .59 & .80 & .73 & .69 & \\
\hline 38 & KEL141 & 16891983 & & & & & .72 & .85 & .80 & .71 & .73 & .63 & .61 & .69 & .77 & .72 & .42 & .50 & \\
\hline 39 & KEL142 & 16901983 & & & & & .71 & .74 & .73 & .70 & .73 & .66 & .52 & .65 & .69 & .80 & .62 & .61 & \\
\hline 43 & ess_02 & 16321993 & & & .74 & .56 & .44 & .46 & .54 & .72 & .81 & .74 & .78 & .80 & .74 & .81 & .66 & .65 & \\
\hline 44 & ess_03 & 16331958 & & & .73 & .65 & .58 & .75 & .86 & .80 & .80 & .82 & .56 & .46 & .65 & .50 & .44 & & \\
\hline 45 & ess_04 & 16591993 & & & & .58 & .58 & .73 & .81 & .73 & .74 & .72 & .58 & .58 & .61 & .77 & .75 & .69 & \\
\hline 46 & ess_05 & 17001993 & & & & & & .70 & .74 & .71 & .76 & .77 & .82 & .80 & .66 & .75 & .58 & .41 & \\
\hline 47 & ess_06 & 16951993 & & & & & .69 & .68 & .71 & .79 & .78 & .71 & .70 & .68 & .65 & .65 & .61 & .66 & \\
\hline 48 & ess_08 & 16331993 & & & .56 & .45 & .62 & .79 & .75 & .69 & .57 & .44 & .73 & .79 & .71 & .80 & .76 & .73 & \\
\hline 53 & ess_13 & 16751993 & & & & & .68 & .55 & .58 & .75 & .81 & .81 & .88 & .79 & .64 & .82 & .76 & .76 & \\
\hline 95 & C:ZZ & 16322003 & & & .90 & .87 & .83 & .88 & .85 & .89 & .91 & .91 & .92 & .91 & .89 & .94 & .88 & .79 & .77 \\
\hline 96 & s1a & 16481683 & & & .65 & & & & & & & & & & & & & & \\
\hline 97 & s1b & 16481680 & & & .46 & & & & & & & & & & & & & & \\
\hline 98 & s2a & 16491707 & & & .51 & .51 & .44 & & & & & & & & & & & & \\
\hline 99 & $\mathbf{s 2 b}$ & 16501686 & & & & .54 & & & & & & & & & & & & & \\
\hline 100 & s3 & 16971747 & & & & & .57 & .58 & & & & & & & & & & & \\
\hline 101 & s6 & 16501688 & & & & .61 & & & & & & & & & & & & & \\
\hline 102 & s7a & 16641738 & & & & .46 & .55 & .38 & & & & & & & & & & & \\
\hline 103 & $\mathbf{s 7 b}$ & 16601737 & & & & .50 & .45 & .38 & & & & & & & & & & & \\
\hline 104 & $\mathrm{~s} 7 \mathrm{c}$ & 16601756 & & & & .43 & .57 & .46 & .40 & & & & & & & & & & \\
\hline 105 & s8a & 16711734 & & & & $.27 \mathrm{~A}$ & .43 & $.30 \mathrm{~A}$ & & & & & & & & & & & \\
\hline 106 & s8b & 16711738 & & & & .39 & .49 & .41 & & & & & & & & & & & \\
\hline 107 & kame6a & 16781938 & & & & & .62 & .78 & .74 & .56 & .41 & .44 & .75 & .69 & .57 & .40 & & & \\
\hline 108 & kame6b & 16781936 & & & & & .63 & .83 & .74 & .56 & .69 & .72 & .78 & .69 & .44 & .45 & & & \\
\hline 109 & kame7a & 15951646 & .72 & .71 & & & & & & & & & & & & & & & \\
\hline 110 & kame7b & 15941646 & .60 & .60 & & & & & & & & & & & & & & & \\
\hline 111 & razn1a & 16361647 & & & .74 & & & & & & & & & & & & & & \\
\hline 112 & razn1b & 16401650 & & & .86 & & & & & & & & & & & & & & \\
\hline 113 & razn5a & 15941646 & .65 & .64 & & & & & & & & & & & & & & & \\
\hline 114 & $\operatorname{razn5b}$ & 15941646 & .58 & .59 & & & & & & & & & & & & & & & \\
\hline 115 & Tsoila & 15841648 & $.27 \mathrm{~B}$ & $.33 A$ & & & & & & & & & & & & & & & \\
\hline 116 & Tsoilb & 16331649 & & & .69 & & & & & & & & & & & & & & \\
\hline 117 & razv1a & 16401655 & & & .76 & & & & & & & & & & & & & & \\
\hline 118 & razv1b & 16401655 & & & .74 & & & & & & & & & & & & & & \\
\hline 119 & razv1c & 16411654 & & & .59 & & & & & & & & & & & & & & \\
\hline 120 & razv3 & 16201642 & & .68 & & & & & & & & & & & & & & & \\
\hline 121 & razv4a & 16021617 & & .56 & & & & & & & & & & & & & & & \\
\hline 122 & $\operatorname{razv} 4 b$ & 16031619 & & .60 & & & & & & & & & & & & & & & \\
\hline 123 & $\operatorname{razv5a}$ & 16281650 & & & .58 & & & & & & & & & & & & & & \\
\hline 124 & razv5b & 16171644 & & .50 & & & & & & & & & & & & & & & \\
\hline 125 & razn2a & 16231646 & & .57 & & & & & & & & & & & & & & & \\
\hline 126 & razn5a & 15941646 & .65 & .64 & & & & & & & & & & & & & & & \\
\hline 127 & $\operatorname{razn5b}$ & 15941646 & .58 & .59 & & & & & & & & & & & & & & & \\
\hline 128 & razn10 & 15931649 & .35 & .37 & & & & & & & & & & & & & & & \\
\hline
\end{tabular}

\subsection{Sub-fossil wood}

\subsubsection{Baidarnaia valley}

Eight carbonized logs buried in the Baidarnaia valley pyroclastic flow deposit were found in August 2003 (Fig. 3). The 2-10 m thick deposit composed of pale fine-grained homogenous pumiceous material was recently exposed in an almost vertical outcrop. The very bottom of the deposit was not ex- posed. The standing position of all the logs indicates that they were buried by the pyroclastic material and carbonized in situ. We collected their uppermost parts exposed by erosion for the tree-ring analyses. The surface of the pyroclastic flow deposit is covered by mixed forest sampled for tree-ring analysis (see also Table 2). 


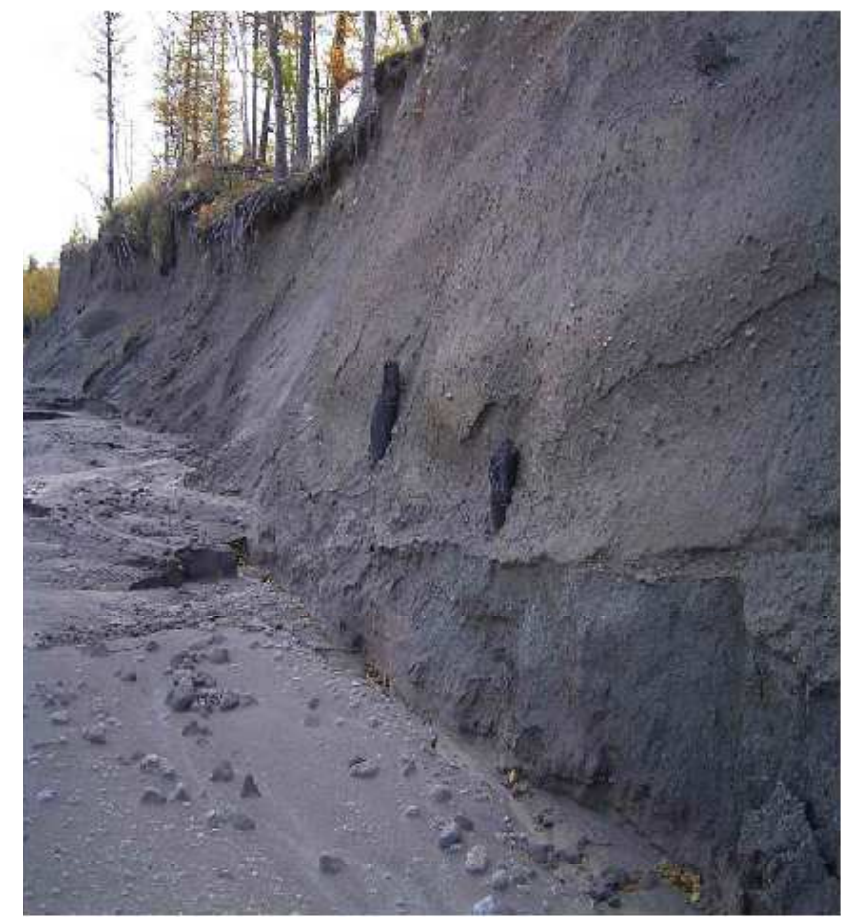

Fig. 3. Carbonized wood buried in a pyroclastic flow in the Baidarnaia valley.

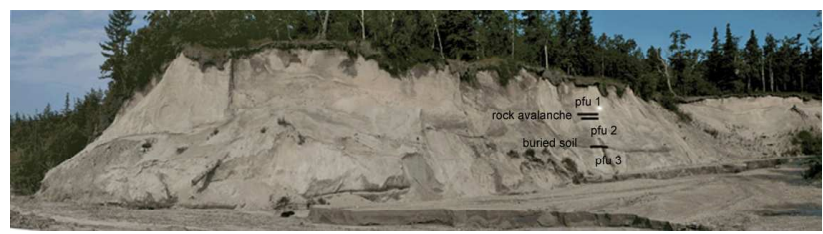

Fig. 4. Section in the Kamenskaia valley ("Razvilka"). Pfu - pyroclastic flow unit.

\subsubsection{Kamenskaia valley}

In summer 2006, we collected 24 tree-ring samples from pyroclastic flow deposits cropping out at the river fork ("Razvilka" outcrop, Fig. 4) and farther up- and downstream.

The 8-10 m high "Razvilka" outcrop (Fig. 4) exposes three pyroclastic flow units (pfu) interlayered with a thin paleosol horizon and a debris avalanche (?) deposit. Pfu 1 and 2 , and a 1-3 m thick debris unit in between are not separated by paleosols, so both pfu may derive from the same eruption. All the pfu are composed mostly of pale fine-grained pumiceous ash that are rich in wood remains of varying quality. The deposits are (from top to bottom): 1) pfu 1;2) a 1-3 m thick debris avalanche deposit; 3) pfu 2; 4) paleosol horizon; 5) pfu 3 . The carbonized wood samples were collected from the second (five samples - RAZV) and third (ten samples - RAZN) pfu (see Fig. 4). Unfortunately most collected wood (except samples RAZN 5 and RAZN 10a) were

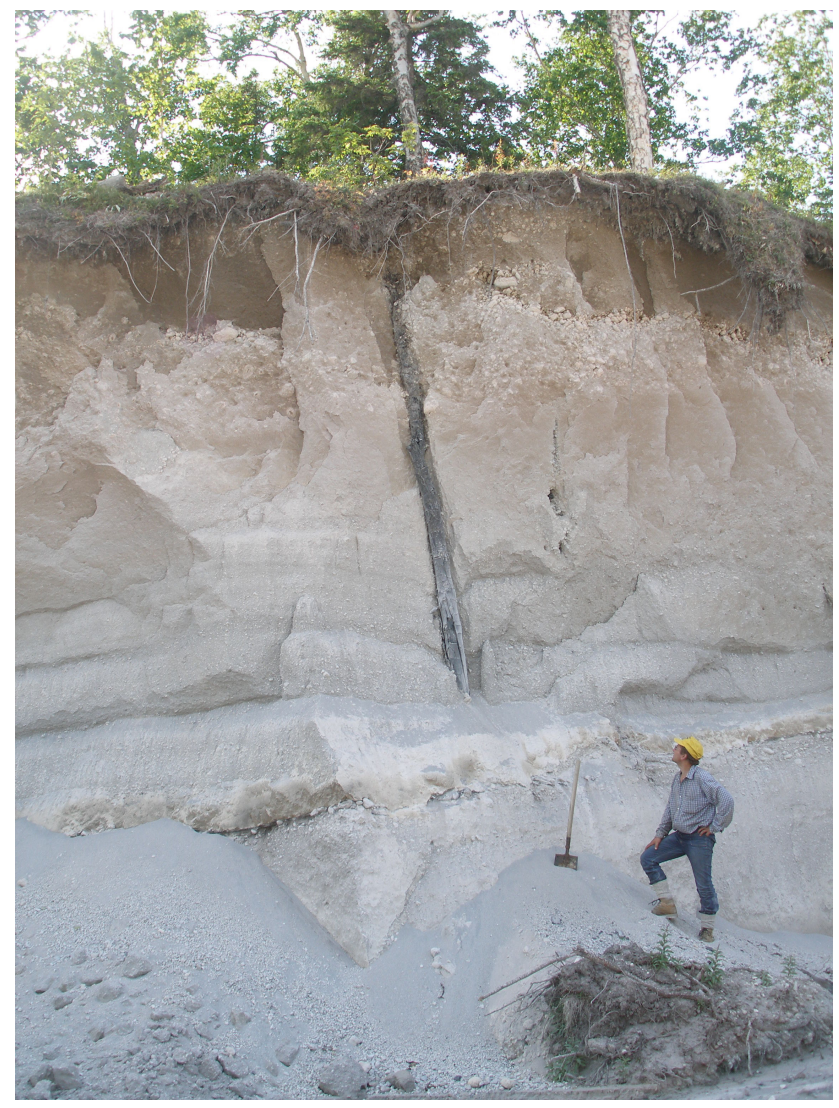

Fig. 5. Sample KAME 7 buried in the pyroclastic flow in Levaia Kamenskaia valley.

very young trees or fragile small pieces of wood with 7-40 rings, which is not enough for reliable dating.

We also collected five wood samples from the "Three soils" site (TSOIL) located downstream of the "Razvilka" outcrop. Three buried soils were identified in the uppermost part of the section separated by the pfu: the wood samples were collected in the uppermost soil horizon. One of these wood samples (TSOIL 2) was tentatively cross-dated against the regional larch chronology.

Upstream of the "Razvilka" site, we collected three carbonized samples from both sides of Kamenskaia river. Only one of these charcoal samples (KAME 7) could be crossdated with the tree burned and buried in situ (Fig. 5).

We do not know exact relationships between different stratigraphic units where our samples were collected because of the difficulties tracing lithologically similar deposits from outcrop to outcrop. However, we presume that some of the units exposed in different outcrops are of the same age due to the close location of the outcrops to each other.

The tree remains buried in the pfu are preserved in varying conditions. Most remains are very fragile charcoals, but some are still useful for the tree-ring dating (Fig. 6). They were found carbonized in standing position, therefore we 
presume that these trees were buried alive by hot volcanic material. Thus, the time of their death corresponds to the date of the volcanic event.

No bark was preserved in most trees, but in some cases it seems that no growth rings were lost in fire due to the smooth surface of the trunk. The age of the outer rings gives us only the minimum possible age, although in some cases we believe that it is close to the real date of the event. The poor wood quality of several samples prevented measurement of all rings. On these occasions we would measure as many as possible and estimate the number of remaining rings toward the pith and the bark.

Due to the poor quality and fragility of many samples we were able to cross date with certainty only a subset of them (11 out of 32). We measured ring-width using standard treering equipment or photographs ( 7 samples), cross-dated them against the larch ring-width regional chronology, and estimated the dates of the outer rings.

\subsection{Cross-dating}

\subsubsection{Baidarnaia valley}

Although some charcoal samples collected in Baidarnaia valley are rather short (less than 40 years), they all cross-date well within the data set as well as against the whole chronology. The length of the reference chronology is sufficient for the ultimate dating in this case. The COFECHA does not suggest any other option for the dating of this site. These findings lead us to believe that the dates for the trees buried in the Baidarnaia pyroclastic flow are reliable.

The latest date of carbonized trees indicates the date of the eruption responsible for the pyroclastic flow emplacement that killed, and buried these trees under the fine-grained pyroclastic products. The most recent date of the whole data set is AD 1756 (sample S7c Tables 4, 5). Although the bark was not preserved, we believe that no more than a very few rings could be lost due to rather smooth surface of the log. Other samples show similar, but slightly older dates (AD 1752, AD 1748, AD 1741) (see Tables 4, 5) and generally support the dating by these minimum age estimates. The best preserved samples, S7 (minimum date AD 1756) and S8 (minimum date $\mathrm{AD}$ 1751) are of solid hard brownish, almost intact wood (see Fig. 6). This is in stark contrast to the fragile black charcoal condition of all other samples. Despite the slightly more recent minimum date of sample S7, we believe that all trees were killed by the same pyroclastic flow around the year 1756, but the two best preserved samples were located outside the major track, resulting in preservation of their outer rings. Three of the six dated trees indicate innermost ring dates varying from AD 1640 to AD 1645. These dates limit the age of previous eruptions (accompanied with pyroclastic flow) in the Baidarnaia valley.

The oldest tree found on the surface of this pyroclastic flow in the mixed forest (site SHE) dates back to AD 1793 (see Ta-

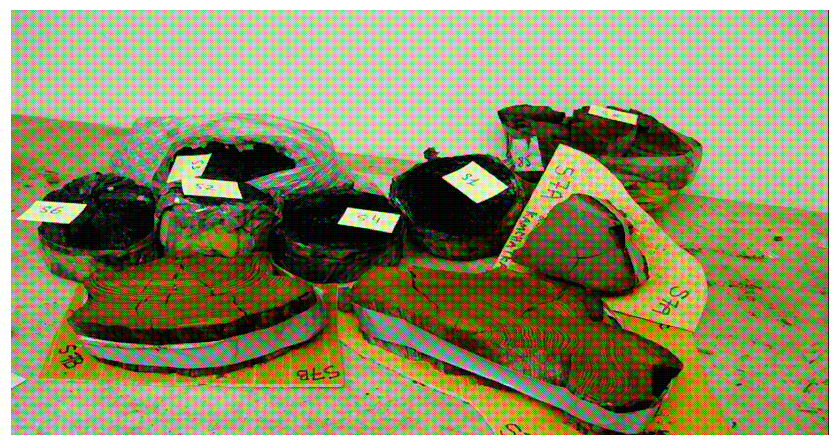

Fig. 6. Samples from the Baidarnaia valley in the laboratory.

ble 2). This allows 37 years for flow colonization by woody vegetation and therefore does not contradict the AD 17561757 deposition date.

\subsubsection{Kamenskaia valley}

Most samples buried in the Kamenskaia sections (see Fig. 4, Tables 4,6 ) are cross-sections from very young small deciduous trees and shrubs. The larger cross-sections are fragile with some portions lost. One tree (KAME 6) buried in the uppermost part of the plu in Kamenskaya section was well-preserved with intact solid wood with bark, but didn't show any trace of possible volcanic influence. The sample was successfully cross-dated (1678-1938) and included in the reference chronology, but its death is not related to any volcanic event. Internal cross-dating of samples in this data set shows that the three longest and best preserved charcoal samples (KAME 5, 7 and RAZN 10) cross-date among themselves. The only option to link the whole set of these three samples to the reference chronology provided by COFECHA is the one displayed in Table 4. Other shorter fragments of charcoal in these locations also fit to this interval, although they are too short to provide the ultimate dates. The samples collected from the deposits of Shiveluch $1\left(\mathrm{SH}_{1}\right)$ were previously radiocarbon dated at AD 1641(1652)1663 (Braitseva et al., 1997a; Ponomareva et al., 1998). Our very tentative tree-ring date coincides almost precisely with the radiocarbon date, but this requires further confirmation by future research.

If we accept the reasoning above, the best preserved charcoal wood sample KAME 7 (Fig. 5) was burned and buried around AD 1649 following tree establishment around AD 1588. Two other samples in Kamenskaia valley yielded similar dates, RAZN 10 (AD 1593-1649) and RAZN 5 (AD 1589-1646), both found in the pfu 3 horizon in the "Razvilka" site (see Fig. 4, Table 6). 
Table 5. Cross-dated charcoal samples in Baidarnaia valley.

\begin{tabular}{|c|c|c|c|c|c|c|c|c|}
\hline \multirow{2}{*}{$\begin{array}{l}\text { Tree } \\
1 \mathrm{a}\end{array}$} & \multicolumn{2}{|c|}{ Measured interval } & \multirow{2}{*}{ 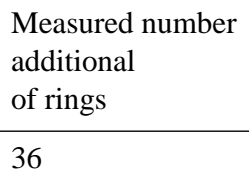 } & \multirow{2}{*}{$\begin{array}{l}\text { Estimated } \\
\text { outer rings } \\
\sim 30\end{array}$} & \multirow{2}{*}{$\begin{array}{l}\text { Inner year } \\
\sim 1645\end{array}$} & \multirow{2}{*}{$\begin{array}{l}\text { Outer year } \\
\sim 1713\end{array}$} & \multirow{2}{*}{$\begin{array}{l}\text { Measure method } \\
\text { photo }\end{array}$} & \multirow{2}{*}{$\begin{array}{l}\text { Comments } \\
\text { charcoal, near pith }\end{array}$} \\
\hline & 1648 & 1683 & & & & & & \\
\hline $1 b$ & 1648 & 1680 & 33 & & $\sim 1645$ & & photo & charcoal, near pith \\
\hline $2 \mathrm{a}$ & 1649 & 1707 & 59 & $\sim 20-25$ & $\sim 1640$ & $\sim 1730$ & photo & charcoal \\
\hline $2 b$ & 1650 & 1686 & 37 & & $\sim 1640$ & & photo & charcoal \\
\hline 3 & 1697 & 1747 & 51 & $\sim 5$ & $\sim 1680$ & $\sim 1752$ & photo & charcoal \\
\hline 4 & & & $50 ?$ & & & & photo & charcoal, destroyed \\
\hline 5 & & & $?$ & & & & photo & charcoal, destroyed \\
\hline 6 & 1650 & 1688 & 39 & $\sim 20$ & $\sim 1640$ & $\sim 1708$ & photo & charcoal \\
\hline $7 \mathrm{a}$ & 1664 & 1738 & 75 & & & & microscope & intact wood \\
\hline $7 b$ & 1660 & 1737 & 78 & & & & microscope & intact wood, pith \\
\hline $7 \mathrm{c}$ & 1660 & 1756 & 97 & 0 & 1660 & 1756 & microscope & intact wood, pith \\
\hline $8 \mathrm{a}$ & 1671 & 1734 & 64 & $\sim 10 ?$ & 1668 & 1751 & microscope & intact wood, pith \\
\hline $8 b$ & 1671 & 1738 & 68 & $\sim 10 ?$ & & & microscope & intact wood, pith \\
\hline
\end{tabular}

Table 6. Tentative cross-dating results of wood samples in Kamenskaia valley (sections with at least two dated segments).

\begin{tabular}{|c|c|c|c|c|c|c|c|c|c|}
\hline Tree & $\mathrm{D}, \mathrm{mm}$ & $\begin{array}{l}\text { Measured } \\
\text { inner ring }\end{array}$ & $\begin{array}{l}\text { Measured } \\
\text { outer ring }\end{array}$ & $\begin{array}{l}\text { Number of } \\
\text { measured rings }\end{array}$ & $\begin{array}{l}\text { Estim. of } \\
\text { additional } \\
\text { inner rings }\end{array}$ & $\begin{array}{l}\text { Estim. of } \\
\text { additional } \\
\text { outer rings }\end{array}$ & $\begin{array}{l}\text { Final date of } \\
\text { inner rings }\end{array}$ & $\begin{array}{l}\text { Final date of } \\
\text { outer ring }\end{array}$ & Comments \\
\hline $\begin{array}{l}\text { RAZN 5a } \\
\text { RAZN 5b }\end{array}$ & 110 & 1594 & 1646 & 52 & up to 5 & ? & 1589 & 1646 & $\begin{array}{l}\text { charcoal with many } \\
\text { radial and lateral cracks, } \\
\text { well preserved }\end{array}$ \\
\hline RAZN 10a & 260 & 1593 & 1649 & 56 & $?$ & $?$ & 1593 & 1649 & $\begin{array}{l}\text { fragile piece of charcoal, } \\
\text { poorly preserved, no pith }\end{array}$ \\
\hline KAME 6a & 300 & 1678 & 1938 & 260 & $20-30$ & 0 & 1678 & 1937 & wood in very good \\
\hline KAME $6 b$ & 300 & 1678 & 1936 & 258 & 0 & 1 & & & condition, with pith and bark \\
\hline KAME 7a & 150 & 1595 & 1646 & 51 & $8-10$ & $2-3$ & 1588 & 1649 & $\begin{array}{l}\text { charcoal sample in good } \\
\text { condition; the whole log } \\
\text { was preserved from the } \\
\text { bottom to the top of } \\
\text { the section in a piece } \\
\text { in vertical position, } \\
\text { measured with microscope } \\
\text { and photo }\end{array}$ \\
\hline
\end{tabular}

5.3 Comparison of "volcanic" and "non-volcanic" reference chronologies

Apart from the samples buried in the volcanic deposits, two larch and one spruce chronologies were developed from the slopes of Shiveluch volcano in the Baidarnaia and Pravaia Kamenskaia valleys (see Fig. 1). The mature trees of these chronologies survived many eruptions. In Figs. 7 and 8 we compare these chronologies with those from the undisturbed sites elsewhere in Kamchatka. In general, the "volcanic" and "non-volcanic" chronologies, both for larch and spruce, are well correlated among the same species except for the very early period (17th century) when the replication of the larch chronologies is quite low and some samples are charcoal with more difficult and uncertain tree-ring measuring and dating.

The results of this comparison are shown in Figs. 7 and 8 and Table 7. In Table 7, we compare the dates of ringwidth outliers smaller than one standard deviation. The light gray cells indicate years with outliers in both the "volcanic" and "non-volcanic" chronologies, and, hence listing the marker years across the region, most probably, of climatic or other non-volcanic origin (e.g. 1995, 1990, 1986, 

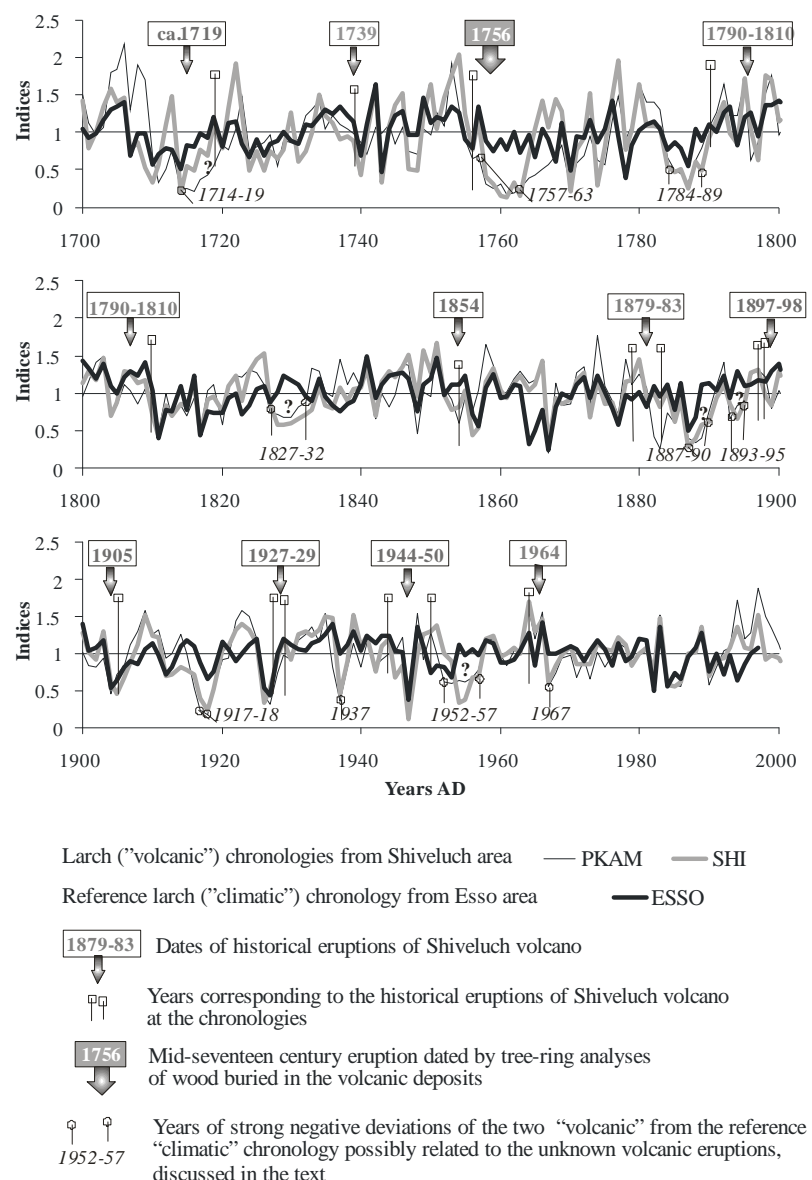

Fig. 7. Larch chronologies in Esso (non-volcanic region), Baidarnaia (SHI) and Kamenskaia (PKAM) valleys, Shiveluch.

1947,1918 , etc.). The dark gray cells are outlier years in only the "volcanic" chronologies and they are considered years of potentially volcanic activity, or at least of local origin in the Shiveluch area. Seven dates fit these criteria: 1967, 1937, 1917, 1889, 1786-1785, 1762-1760, 1715. However, none of these dates coincide with the known dates of eruptions listed in Table 1. The reason this test fails is most probably connected to our interest in relative, but not absolute ringwidth decrease. Therefore, a less formal approach of visual comparison of the ring-width indices of "volcanic" and "nonvolcanic" chronologies (Figs. 7 and 8) proved more informative in this study.

Below we discuss the results of our dating as well as the potential volcanic signal embedded in our ring-width chronologies in the context of historical and tephrochronological data. We describe case by case the historically and stratigraphically recorded eruptions of Shiveluch in calendar order to detect their potential signal in our ring-width chronologies and compare them with the results of the dating of buried wood (Figs. 7 and 8).
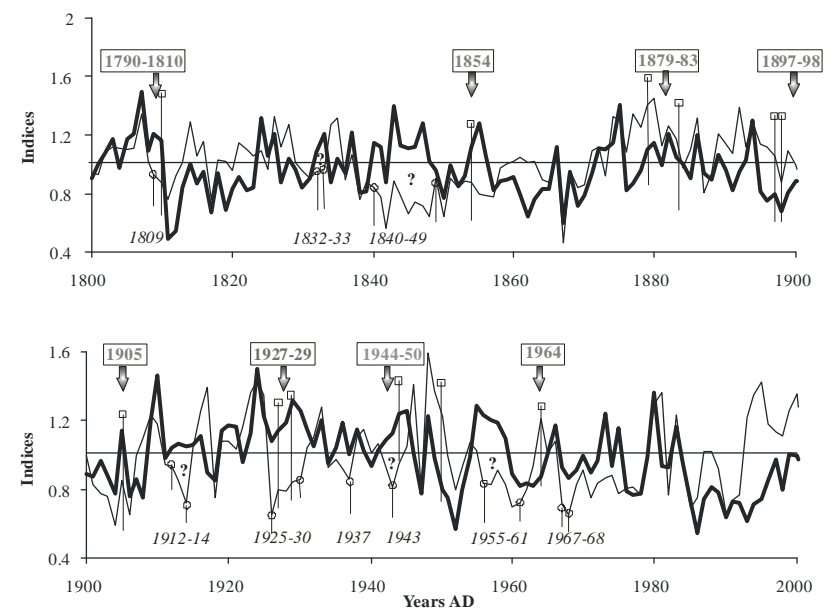

Spruce ("volcanic") chronology from Shiveluch area - SHE

Reference spruce ("climatic") chronology from Kamchatka river valley —URZ

Fig. 8. Spruce chronologies in URZ valley (non-volcanic region) and in the Baidarnaia valley at Shiveluch volcano (see Fig. 7 for captions).

The eruption of November AD 1964 was one of the strongest among all historically recorded. It produced tephra falls and pyroclastic flows. Due to its force and major influence on the landscape, we expected to see evidence of this eruption in the local tree-ring chronologies during the next vegetation season in AD 1965. However, the nearest growth suppression in the "volcanic" chronologies dates to 1967 ; too late to be related to this eruption. Both "volcanic" chronologies show a slight growth decrease in 1965, but this decrease is of negligible scale and it is in concert with the decrease of ring-widths as observed in the "non-volcanic" ESSO chronology. Thus we do not see a clear evidence of this eruption in our records.

Prior to the AD 1964 event, there was an eruption that started in November AD 1944 and ended up in April AD 1950. During this eruption a new dome (Suelich) was formed. Numerous hot avalanches and ash falls followed the growth of the dome (Meniailov, 1955). The discrepancy between "volcanic" and "non-volcanic" spruce chronologies occurs in AD 1943, i.e. two years earlier than indicated by the historical date of eruption. However, taking into consideration the very sparse population in the area and the low scientific activity during the Second World War, we do not exclude that this period of volcanic activity may have begun one year earlier. One larch (SHI) chronology from Shiveluch shows minor growth suppression in 1945, although in 1946 the SHI curve is back in agreement with the "non-volcanic" ESSO chronology. It is of interest that during this eruption the "volcanic" spruce chronology considerably exceeded normal tree ring widths in the years 1946 and 1948. 
Table 7. Ring-width minima exceeding one standard deviations in three "volcanic" (SHI, PKAM and SHE, bold) and two reference chronologies (plain). Light shaded cells - the case of coincidence of the dates in the "volcanic" and "non-volcanic" chronologies, dark gray cells - minima recorded only in "volcanic" chronologies.

\begin{tabular}{|c|c|c|c|c|}
\hline SHI Larch & Pkam Larch & ESSO Larch & URZ Spruce & SHE Spruce \\
\hline & & & 1995 & 2002 \\
\hline & & 1994 & 1994 & \\
\hline & & & 1993 & \\
\hline & & 1992 & 1992 & 1992 \\
\hline & & & 1991 & 1991 \\
\hline & 1990 & 1990 & 1990 & 1990 \\
\hline & & & 1989 & \\
\hline & & & 1987 & \\
\hline 1986 & 1986 & 1986 & 1986 & 1986 \\
\hline 1985 & 1985 & 1985 & 1985 & 1985 \\
\hline \multirow[t]{10}{*}{1984} & 1984 & 1984 & & \\
\hline & 1983 & & & \\
\hline & 1982 & 1982 & & 1982 \\
\hline & & & 1978 & 1978 \\
\hline & & & 1977 & 1975 \\
\hline & & & & 1971 \\
\hline & & & & 1968 \\
\hline & 1967 & & & 1967 \\
\hline & & & & 1961 \\
\hline & & & & 1960 \\
\hline 1955 & & 1953 & 1952 & \\
\hline 1954 & & 1950 & 1951 & \\
\hline 1947 & 1947 & 1947 & 1947 & \\
\hline 1937 & 1937 & & & \\
\hline 1927 & 1927 & 1927 & & \\
\hline 1926 & 1926 & 1926 & & 1926 \\
\hline 1919 & 1919 & 1919 & & \\
\hline 1918 & 1918 & 1918 & & 1918 \\
\hline 1917 & 1917 & 1912 & 1908 & 1914 \\
\hline \multirow[t]{2}{*}{1905} & 1916 & 1905 & 1906 & 1906 \\
\hline & 1904 & 1904 & 1904 & 1904 \\
\hline 1889 & 1889 & & & \\
\hline 1888 & 1888 & 1888 & 1898 & 1903 \\
\hline 1887 & 1887 & 1887 & 1896 & 1902 \\
\hline \multirow[t]{2}{*}{1877} & 1883 & 1877 & 1869 & \\
\hline & 1882 & & & \\
\hline \multirow[t]{3}{*}{1867} & 1867 & 1867 & 1867 & 1867 \\
\hline & & 1865 & & \\
\hline & & 1864 & 1863 & \\
\hline 1857 & & 1857 & 1862 & 1857 \\
\hline 1856 & & 1856 & & 1856 \\
\hline
\end{tabular}

The eruption that occurred in AD 1927-1929 was weak. Gorshkov and Dubik (1970) suggest that this eruption did not much change the landscape in the Shiveluch area based on comparison of the AD 1909 and AD 1949 photos. The treering evidence are again ambiguous: while larch chronologies did not show any volcanic signal at that time, the spruce "volcanic" chronology (SHE) has a suppression which does not correspond with the climatic curve in the "non-volcanic" chronologies, but this suppression begins earlier (in 1925) and ends later (in 1930) than the eruption.
Table 7. Continued.

\begin{tabular}{|c|c|c|c|c|}
\hline SHI Larch & Pkam Larch & ESSO Larch & URZ Spruce & SHE Spruce \\
\hline & & & 1850 & 1850 \\
\hline & 1848 & 1848 & & 1848 \\
\hline 1830 & & 1837 & & 1847 \\
\hline 1829 & & 1823 & & 1846 \\
\hline \multirow[t]{4}{*}{1828} & & 1820 & & 1845 \\
\hline & & 1819 & 1819 & 1842 \\
\hline & & 1818 & & 1841 \\
\hline & & & & 1838 \\
\hline \multirow[t]{2}{*}{1817} & 1817 & 1817 & 1817 & 1817 \\
\hline & & & 1812 & \\
\hline 1811 & 1811 & 1811 & 1811 & 1811 \\
\hline 1788 & & & 1798 & \\
\hline 1787 & 1787 & 1787 & 1797 & \\
\hline 1786 & 1786 & 1778 & 1796 & \\
\hline 1785 & 1785 & & 1794 & \\
\hline 1784 & & & 1793 & \\
\hline 1774 & & & 1771 & \\
\hline \multirow[t]{5}{*}{1770} & 1770 & 1770 & 1770 & \\
\hline & 1767 & 1768 & & \\
\hline & 1766 & & & \\
\hline & 1765 & 1765 & & \\
\hline & 1764 & & & \\
\hline 1763 & 1763 & 1763 & & \\
\hline 1762 & 1762 & & & \\
\hline 1761 & 1761 & & & \\
\hline 1760 & 1760 & & & \\
\hline 1759 & 1759 & 1759 & 1759 & \\
\hline 1758 & 1758 & & 1758 & \\
\hline \multicolumn{5}{|l|}{1748} \\
\hline \multicolumn{5}{|l|}{1747} \\
\hline 1743 & & 1743 & & \\
\hline 1740 & & 1740 & 1735 & \\
\hline 1731 & & & 1734 & \\
\hline 1726 & 1728 & 1726 & 1727 & \\
\hline \multirow{5}{*}{1724} & & & 1723 & \\
\hline & & & 1720 & \\
\hline & 1719 & & 1719 & \\
\hline & 1718 & & 1718 & \\
\hline & 1717 & & & \\
\hline 1716 & 1716 & & 1716 & \\
\hline 1715 & 1715 & & & \\
\hline \multirow[t]{2}{*}{1714} & 1714 & 1714 & 1713 & \\
\hline & 1712 & & & \\
\hline 1711 & 1711 & 1711 & & \\
\hline 1710 & & 1710 & & \\
\hline 1709 & & 1707 & 1703 & \\
\hline
\end{tabular}

No sign of the influence of the historical eruption of 1905 can be found in our chronologies in the years 1905 or 1906, however the historical evidence of this eruption is not very solid (Gorshkov and Dubik, 1970).

Activity of the central dome of Shiveluch, including tephra ejections and explosions, was recorded in AD 18971898 (Gorshkov and Dubik, 1970). Both "volcanic" larch chronologies in Baidarnaia and Kamenskaia valleys show growth suppression in 1899 (Figs. 7 and 8). One can identify similar features in the larch chronologies in 1887-1890 and 1893-1895 as well (Fig. 7). This may indicate that this period of volcanic activity could have begun a decade earlier. 
A four-year long moderate eruption associated with the lava dome formation was recorded in 1879-1883 (Gorshkov and Dubik, 1970). The larch chronology in Kamenskaia valley shows growth suppression in 1882-1883. However, in the beginning of the eruption period there is a positive growth anomaly both for spruce and larch in the region.

Ditmar (1890) described a catastrophic eruption of Shiveluch on 17-18 February AD 1854. Later, Gorshkov and Dubik (1970) and Meniailov (1955) summarized the descriptions of this eruption, based mostly on observations by residents. They described: (i) increased fumarole activity on the northern side of Shiveluch during October-December 1853; (ii) the failure of the summit of the volcano during the night of 17-18 February; (iii) extensive lava flows on all the slopes of the volcano reaching Elovka River in the west; (iv) the destruction of forest at the foot of the volcano by enormous stones and the breaking of ice on Elovka and Kamchatka rivers; (v) an ash fall in Kliuchi ( $\sim 45 \mathrm{~km}$ south of the volcano) and Tigil' ( $\sim 200 \mathrm{~km}$ northwest of the volcano). Later studies confirmed that the eruption was very strong but reinterpreted some of the processes. Bogdanowitsch (1904) disproved the reported outpouring of lava. Gorshkov and Dubik (1970) pointed out that the natives could have mistaken pyroclastic and mud flows for lava flows as they did in 1956 while watching the Bezymianny eruption. Ponomareva et al. (1998) did not find any large debris avalanche deposits of this age but mapped extensive tephra fall deposit north of the volcano and extensive lahars south of the latter. Shiveluch chronologies in both Baidarnaia and Kamenskaia valleys show a moderate growth decrease in AD 1853-1857 (spruce) and in AD 1853-1854 (larch) (Figs. 7 and 8) in comparison with the URZ and ESSO reference chronologies, respectively.

The historical evidences of the eruptions in the 1700s and early 1800s are ambiguous and not supported by geological data. Gorshkov and Dubik (1970) suggested that the volcano was dormant during this period, and doubted the existence of the AD 1790-1810 eruptions. Potential tree-ring evidence is weak for Shiveluch eruptions in AD 1790-1810: spruce reduced its growth in 1809 , while the larch curve on the contrary show two "non-climatic" maxima in 1799 and 1795.

The eruption of AD 1756-1757 identified by the crossdating of the wood from the Baidarnaia pyroclastic flow deposit is clearly supported by the growth depression of larch trees in both Baidarnaia and Kamenskaia valleys in AD 1758-1763. We did not find buried wood of the same age in Kamenskaya valley, but the larch growth depression in PKAM (Pravaia Kamenskaia valley) may indicate that the eruption was felt there as well.

The historical evidence of two eruptions in AD 1739 and AD 1719 are rather weak. Krasheninnikov (1755), traveling in the vicinity of Shiveluch in 1739, saw the volcano smoking but he did not approach it. The local people told him that this smoke appeared 20 years ago (i.e. around AD 1719). A slight growth suppression in larch ring-width one to two years be- fore 1739 as well as in AD 1714-1719 may be a sign of this set of eruptions (Fig. 7).

Thus, most of the historical eruptions did not find a strong confirmation in the ring-width chronologies from the trees growing on the slopes of Shiveluch in its southern part. We discuss the potential reasons for this phenomenon in the following section.

\section{Discussion}

\subsection{Dating reliability and accuracy}

Several difficulties should be taken into account in the dating of volcanic events using tree-ring analyses. The first group of problems is common to tree-ring dating of buried wood in general. There must be certainty that the material was in situ and directly connected to the processes responsible for the emplacement of sediments. In our case, all trees except for KAME 6, were killed by the hot pyroclastic flow, carbonized, and buried in situ in a standing position. The KAME 6 sample was not carbonized and the log was lying in the upper layer of the pyroclastic flow, half a meter below the surface. The cause of death of this tree is unclear. The quality of wood is high with no indication of decay and natural death related to old age or disease. The log was buried in the deposits, tentatively identified as lahar sediments.

The major sources of uncertainty concerning the treering dating accuracy involve samples missing their outermost rings. In these cases we provide just a minimum age of the deposits and related eruptions. Unfortunately, due to the absence of bark in the wood buried by the pyroclastic flows, none of our dates can be claimed to have one-year accuracy. Nonetheless, we believe that the date AD 1756-1757 for the eruption of the mid-18th century is close to absolute due to its correspondence with ring-width decrease observed at the same time both in volcanic chronologies of Baidarnaia (SHE) and Kamenskaia (PKAM). The growth suppression after AD 1757 lasted for 8 years in Baidarnaia and for 12 years in Kamenskaia valleys. The length of the suppression depends primarily on the degree of tree damage (Kramer and Kozlowski, 1979), but in this case the multiple eruptions may have caused repeated damage to the same trees. We believe that an additional volcanic impact may have been possible between 1757 and 1763, but likely did not occur during 1764-1769 due to the end of the growth suppression in Baidarnaia and a uniform gradual growth release in Kamenskaia valleys during these later years (see Fig. 7). It is of interest that a similar pattern occurs in the larch chronologies between AD 1714 and 1722 with the growth suppression in 1714-1716 in the SHI volcanic chronology, and a longer suppression with a smooth recovery in the PKAM chronology, in contrast to the "non-volcanic" ESSO chronology. According to historical records (see also Table 1, Fig. 7 and Sect. 5.2), the smoke that Krasheninnikov saw at Shiveluch 


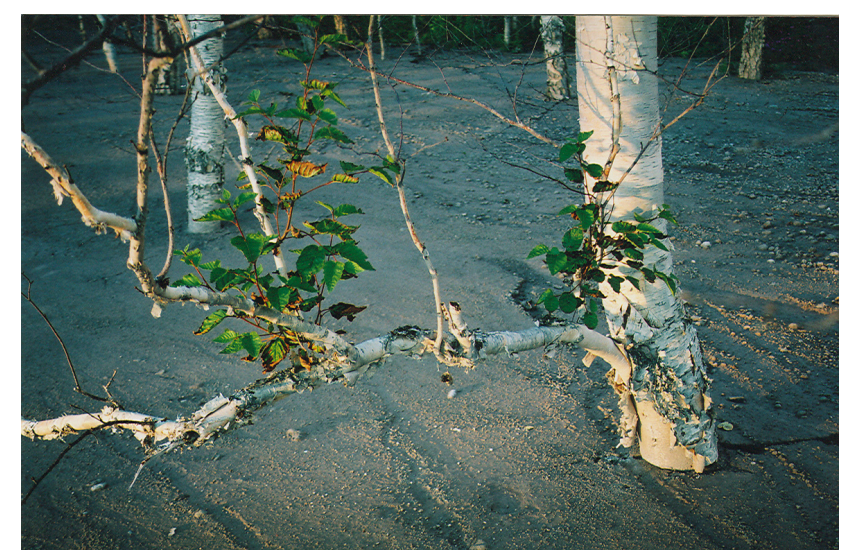

Fig. 9. Birch tree survived the Shiveluch eruption in February 2005 (Photo by M. Pevzner, September, 2005).

in 1739 appeared about 20 years earlier, i.e. very close to the time marked by the irregularities in the volcanic chronologies mentioned above. Although both historical and tree-ring data in this case are far from decisive evidences, this coincidence requires further research.

Yamaguchi and Hoblitt (1995) indicate that one potential source of error in the dating of volcanic events can be delayed tree death or death from unrelated causes (i.e., dead trees incorporated in later deposits). In some cases, trees almost killed by an eruption can survive for several years if some part of the cambium is still preserved. We noticed this phenomenon at Shiveluch volcano after the eruption, lahar, and pyroclastic flow in February 2005, when the bottom of birch trees was buried and most branches were dried and burned (Fig. 9), but a few trees still produced leaves and formed a very narrow ring for 2005 . We did not identify such cases in our samples: most are carbonized wood and were most likely killed by the pyroclastic flow, which can reach temperatures of $300^{\circ} \mathrm{C}$ (Banks and Hoblitt, 1981).

The innermost rings on cross-sections give us an approximate estimate of the minimum age of the surface where the tree grows, and therefore some indirect information on the time elapsed since a previous eruption. However, the actual date of the eruption depends also on the colonization rate, which can be very different depending on the thickness of the ash layer. The ecesis can be as long as a few decades and even centuries if the ash layer is thick enough and the new plant colonization is considered as a primary succession (Grishin et al., 2000). Yamaguchi and Hoblitt (1995) believe that the minimum ages of deposits are underestimated comparatively to their actual emplacement dates by $10-30 \mathrm{yr}$. They claim that at least 20 samples are necessary to obtain the accurate estimate.

\subsection{Eruption of the mid-18th century}

The eruption of AD 1756-1758, identified by the crossdating of wood from the Baidarnaia pyroclastic flow deposit, has never before been mentioned in the literature. This is probably due to the moderate size of the eruption or the general underreporting of the events in this time interval because of the scarcity of the population and its illiteracy. The wellconstrained dates of charcoal, growth depression of larch trees in Baidarnaia and Kamenskaia valleys, and the age of the trees growing on the surface of the pyroclastic flow all provide strong evidence that an eruption took place after AD 1756, most probably in 1758 . We did not find buried wood of the same age in the Kamenskaya valley, but the larch growth depression in PKAM (Pravaia Kamenskaia valley) may indicate that the eruption was felt there as well. This is also supported by a tephrochronological finding of a minor pyroclastic flow deposit between the AD 1854 and SH1 deposits in the upper reaches of Kamenskaia (Ponomareva et al., 2007).

\subsection{Eruption of mid-17th century $\left(\mathrm{SH}_{1}\right)$}

Our reference chronology is too short for a definitive dating of an eruption of the mid-17th century. However, there are some reasons that favor our tentative date. According to tephrochronological data, one of the largest Shiveluch eruptions $\left(\mathrm{SH}_{1}\right)$ occurred ca. $250{ }^{14} \mathrm{C}$ years BP (Braitseva et al., 1997a; Ponomareva et al., 1998, 2007). A calibrated date for this eruption was estimated at AD 1641(1652)1663 (Braitseva et al., 1997a). The eruption produced pumice fall and voluminous ignimbrite $>22 \mathrm{~km}$ long, and caused extensive debris flows (lahars) down all the valleys. Pyroclastic flows were dispersed mostly in the southern sector. The present day thickness of compacted $\mathrm{SH}_{1}$ tephra in Kliuchi town, $\sim 45 \mathrm{~km}$ to the southwest, is $\sim 4 \mathrm{~cm}$.

Before our tree-ring analyses, tephrochronologists considered the deposits that we studied in Kamenskaya and Baidarnaia valleys as those of the mid-17th century Shiveluch-1 eruption. Ponomarvea et al. (2007) described carbonized spruce trunks still standing in an upright position as prominent features of $\mathrm{SH}_{1}$ deposits on the southern slope of the volcano. Three burned trees buried in situ in Kamenskaia valley yielded the tentative tree-ring dates of $\mathrm{AD} 1646$, $\mathrm{AD} 1649$ and $\mathrm{AD}$ 1649. As there is no bark preserved for these samples, these are only minimum dates. However, the smooth outside surface of the wood suggests that no major ring loss occurred and therefore the dates are close to absolute. Three short wood fragments provide later dates (AD 1650, 1655), but at least two of them (RAZV 1 and RAZV 5) are buried in the upper pfu 1 (see Fig. 3) and therefore they may belong to a different, later eruption. On the other hand, we do not exclude the possibility that the Shiveluch 1 eruption occurred around AD 1655, as the pfu1 and pfu 2 could be also simultaneous (see Sect. 3). However, the 
poor preservation of these samples and the lack of definitive dating do not allow any stronger statement in this respect.

Despite the uncertainty dating the 17 th century eruption, we determined through tree-ring analyses that the AD 17561758 eruption that emplaced pyroclastic flows in Baidarnaia valley were different from the canonic Shiveluch 1, which occurred a century earlier. This information is important for the estimate of the cycles of Shiveluch volcanic activity and the forecast of its future behavior.

The exact correlation of the dates obtained by tree-ring analyses and the tephrochronological units are rather complex at this stage. Many fall deposits from Shiveluch look similar and therefore can sometimes be difficult to identify (Ponomareva et al., 2007). However, the very good correlation between the results of tree-ring analyses and tephrochronology demonstrated in this paper opens opportunities to further refine the stratigraphy and constrain the dates of volcanic events in this area.

6.4 Growth suppression/release in the "volcanic" chronologies in comparison with the "non-volcanic" chronologies

This method was used as a supplementary attempt to test how well these types of records support the historical data and new tree-ring dates of eruptions. Our results show that extreme care is necessary when interpreting this kind of signal, even when dealing with trees growing in close vicinity to the center of volcanic activity. It is evident that we cannot expect to find all eruptions mentioned in the historical records and recorded in the geological sediments in the ringwidth chronologies for several reasons. First and probably the most importantly, trees must be directly damaged either mechanically or chemically to form a narrow ring(s) in response (Yamaguchi, 1993). The "smoke" often described in the historical documents as a sign of the eruption, most probably will not produce any direct effect on the trees growing several kilometers away from the crater. Even if the eruption is followed by a great landscape deformation (pyroclastic flow, lahars etc.), these dramatic changes usually happen in limited locations, therefore even if in one valley we find a pyroclastic flow several kilometers long and a few meters thick, in the next valley this event may not have happened and therefore the eruption is not recorded dendrochronologically.

Even if the trees are damaged in a volcanic event, if the resulting ring-width decrease coincides with a regional cooling, we may loose this information concerning the volcanic eruption, because both circumstances potentially lead to the decrease of ring-width. Hence, using this approach alone a certain number of eruptions may be lost. One can also get confused comparing the tree-ring records with the poorly constrained historical data: the eruption may have begun earlier and ended later than is recorded in the anecdotal stories, because people have always lived quite far away from Shiv-

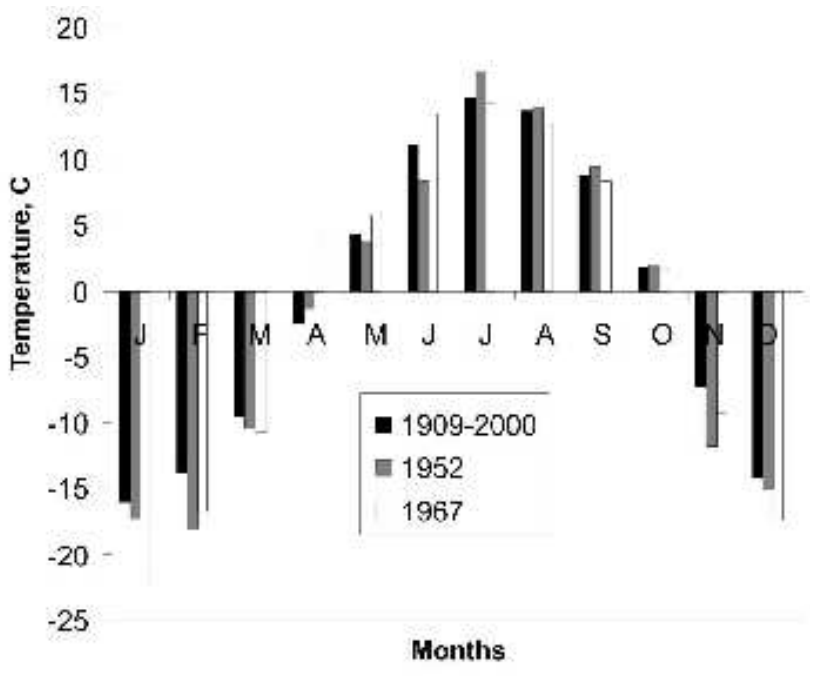

Fig. 10. Mean monthly temperature in 1952 and 1967 in comparison for the mean for 1909-2000 (with gaps) (Kliuchi meteorological station).

eluch volcano. Therefore, in some cases when our tree-ring records slightly pre-date or post-date the historical dates of volcanic event (e.g. the eruption in 1927-1929 and the signal in 1925-1930), it is not possible to determine which dates are correct without additional information from further research or alternative approaches.

Another potential bias of this method is that the disagreement between the chronologies can be partly explained by their different sample replication and as a consequence, different properties of the chronologies. While our regional larch chronology is quite well replicated (up to 110 samples) the local chronologies used for the comparison have a much smaller sample depth and therefore some of their characteristics can be different (including higher variability of ring-width in less replicated chronologies). Evidence of potential volcanic activity is more convincing if all "volcanic" chronologies derived from two different species in two different valleys show a growth suppression in contrast to the reference chronologies (e.g. in 1854) or at least for two of them (e.g. 1757-1763). However, we cannot also rule out that potential local events unrelated to the volcano could lead to disagreement between the reference and the "volcanic" curves (such as local insect attacks, climatic change or even anthropogenic disturbances).

A few cases of clear disagreement between the "volcanic" and reference chronologies are not supported by any historical data of eruptions, e.g. 1967-1968, 1952-1957 (19551961 for spruce), and 1827-1832 (1832-1833 for spruce). It is almost impossible that a volcanic eruption would have occurred unrecorded in the 1950s or 1960s due to rather extensive research in this area during this time. The growth suppression in the 1950s can be explained by temperature 
anomalies (Fig. 10): at Kliuchi, the June air temperature in the years 1952 and 1953 was the second lowest during the entire period after $1919\left(8.3^{\circ} \mathrm{C}\right.$, and $7.6^{\circ} \mathrm{C}$ in comparison with the monthly mean of $11.1^{\circ} \mathrm{C}$ for $1909-2000$, with gaps). The lower than average May temperature during the period 1950-1961 can plausibly explain the suppressed larch growth during this decade, due to the strong correlation of the larch chronology ring-widths with May-June temperatures. However, there were no negative spring-summer temperature anomalies in the Kliuchi records in 1967-1968. The Kliuchi temperature in 1967 was rather low in May $\left(4.3^{\circ} \mathrm{C}\right.$ in comparison with the $1931-1991$ years average $5.8^{\circ} \mathrm{C}$ ) but high in June $\left(13.4^{\circ} \mathrm{C}\right.$ in comparison with the $1931-1991$ years average $11.1^{\circ} \mathrm{C}$ ), and also higher than normal in April. Meanwhile, the warm temperatures in April (see Fig. 2) clearly have negative influence both on spruce and larch in Kamchatka. This comparison shows that ironically the "volcanic" chronologies are sometimes more sensitive to climatic extremes than the "non-volcanic" reference ESSO and URZ chronologies. This sensitivity is not surprising taking into consideration the extremely stressful growth conditions at the upper tree limit at Shiveluch slopes.

Positive growth anomalies can be also related to the volcanic activity either directly by the soil fertilization with a thin layer of ash rich in mineral components or indirectly by removing the neighboring plants and reducing competition for sunlight and other resources. In both these cases we can expect positive growth anomalies after the eruption. As with the growth suppression of volcanic origin, this effect is local and is not likely to occur in all samples or data sets. Indeed in our chronologies we do not find clear cases of this kind.

\section{Conclusions}

In this paper, we used different approaches to identify periods of activity of Shiveluch volcano: direct cross-dating of samples buried in situ, the dates of the inner rings to identify the duration of quiet periods between the eruptions as well as the deviations of "volcanic" ring-width chronologies from the "climatic" reference chronologies as an additional support for the dating and ambiguous early historical evidences. All these approaches together proved to be very useful for the purpose of this study.

Using tree-ring analyses we have identified a previously unknown eruption of Shiveluch volcano in AD 1756-1758. This eruption produced pyroclastic flow deposits in the Baidarnaia valley at the southwestern slope of the volcano and damaged larch trees at the upper tree limit in Baidarnaia and Kamenskaia valleys.

The eruption of 1756-1758 was different from the Shiveluch-1 eruption which was previously dated by ${ }^{14} \mathrm{C}$ method, at AD 1641(1652)1663 (calibrated age). We found three buried and carbonized stumps which cross-date internally and provide a tentative date of the eruption close to the radiocarbon date (AD 1649). This very large explosive eruption took place about 50 years earlier than the arrival of the first Russian cossacks to Kamchatka, explaining its absence from historical chronicles.

Some historical eruptions of Shiveluch volcano are confirmed by our tree-ring data as well, others are not. In several cases, especially for records earlier than the mid-19th century events, the disagreement between the evidence types might be due to doubtful historical data, in others it may be related to some limitations of the tree-ring approach (namely the coincidence of "non-volcanic" and "volcanic" signals, the absence of appropriated material for dating etc.). Despite of some problems related to the identification of volcanic signal in tree-ring chronologies, fragility and incompleteness of some samples etc., the tree-ring method has proved to be a useful tool for the refinement of the reconstruction of recent history of Shiveluch volcano.

Acknowledgements. This paper would not be possible without the help in the field of our friends and colleagues Yaroslav Muraviev, Vladimir Mikhalenko, and Stanislav Kutuzov. We are also grateful to Markus Stoffel and anonymous reviewers for valuable comments. The research was partly supported by grants from the Russian Foundation for Basic Research \#07-05-00410 and NSF grant \#EAR-0125787 to Joanne Bourgeois.

Edited by: M. Stoffel

Reviewed by: three anonymous referees

\section{References}

Banks, N. G. and Hoblitt, R. P.: Summary of temperature studies of deposits, in: The 1980 eruptions of Mount St. Helens, edited by: Lipman, P. W. and Mullineaux, D. R., Washington, US Geological Survey Professional Paper, 1250, 295-313, 1981.

Belousov, A. B.: The Shiveluch volcanic eruption of 12 November 1964 - explosive eruption provoked by failure of the edifice, J. volcanol. Geoth. Res., 66, 357-365, 1995.

Bogdanowitsch, K.: Geologische Skizze von Kamtschatka, Peterm. Geogr. Mitt., H.3, Gotha. 1904.

Braitseva, O. A., Sulerzhitsky, L. D., Ponomareva, V. V., and Melekestsev, I. V.: Geochronology of the greatest Holocene explosive eruptions in Kamchatka and their imprint on the Greenland glacier shield, Dokl. Earth Sci., 352, 1, 138-140, 1997a, (in Russian).

Braitseva, O. A., Ponomareva, V. V., Sulerzhitsky, L. D., Melekestsev, I. V., and Bailey, J.: Holocene key-marker tephra layers in Kamchatka, Russia, Quaternary Res., 47, 125-139, 1997b, (in Russian).

Briffa, K. R., Jones, P. D., Schweingruber, F. H., and Osborn, T. J.: Influence of volcanic eruptions on Northern Hemisphere summer temperature over the past 600 years, Nature, 393, 450-455, 1998.

Cook, E. R. and Kairiukstic, L. A.: Methods of dendrochronology: applications in the environmental sciences. Dordrecht, Netherland, Kluwer Academic Publishers, 1990.

Ditmar, K.: Reisen und Aufenthalt in Kamtschatka in den Jahren 1851-1855, Th. 1. Beitrage zur Kenntniss des Russischen Reiches, Bd. 7, Spb, 1890. 
Erman A.: Reise um die Erde. Bd. 3. Die Ochozker Kuste, das Ochozker Meer und die Reise auf Kamtschatka im Jahre, 1829, Berlin, 1848.

Filion, L., Payette, S., Gauthier, L., and Boutin, Y.: Light rings in Subarctic conifers as a dendrochronological tool, Quaternary Res., 26, 272-279, 1986.

Furuta, F., Sano, M., and Sweda, T.: Summer temperature trend over the past 400 years for Central Kamchatka reconstructed from tree-rings, in: Geothermal/Dendrochronological paleoclimate reconstruction across eastern margin of Eurasia, edited by: Yamano, M., Nagao, T., and Sweda, T., Matsuyama, Japan, 9299, 2002.

Gorshkov, G. S. and Dubik, Y. M.: Gigantic directed blast at Shiveluch volcano (Kamchatka), B. Volcanol., 34, 261-288, 1970, (in Russian).

Gostev, M., Wiles, G., D’Arrigo, R., Jacoby, G., and Khomentovsky, P.: Early summer temperature since 1670 AD for Central Kamchatka reconstructed based on a Siberian larch tree-ring width chronology, Can. J. Forest. Res., 6, 2048-2052, 1996.

Grishin, S. Y., Krestov, P. V., Verkholat, V. P., and Yakubov, V. V.: The recovery of vegetation on Shiveluch Volcano after the catastrophic eruption in 1964, Komarovskiye Chteniya, 44, 73104, 2000, (in Russian).

Holmes, R.: Dendrochronology program library - users manual, Tucson, Arizona, 1994.

Jacoby, G. C., Workman, K., D'Arrigo, R. D.: Laki eruption of 1783, tree rings, and disaster for northwest Alaska Inuit, Quaternary Sci. Rev., 18, 1365-1371, 1999.

Jones, P. D., Briffa, K. R., and Schweingruber, F. H.: Tree-ring evidence of the widespread effects of explosive volcanic eruptions, Geophys. Res. Lett., 22(11), 1333-1336, 1995.

Kramer, P. J. and T. T. Kozlowski: Physiology of Woody Plants, Academic Press, New York, 811 pp., 1979.

Krasheninnikov, S.: Description of Kamchatka land, Spb, 2nd edition, 1755.

LaMarche, J. V. C. and Hirschboeck, K. K.: Frost rings in trees as records of major volcanic eruptions, Nature, 307, 121-128, 1984.
Melekestsev, I. V., Volynets, O. N., Ermakov, V. A., Kirsanova, T. P., and Masurenkov, Yu. P.: Shiveluch volcano, in: Active volcanoes of Kamchatka, edited by: Fedotov, S. A. and Masurenkov, Y. P., 1, 84-92, Nauka Press, Moscow, 1991, (in Russian).

Meniailov, A. A.: Shiveluch volcano - geological structure, composition of products and eruptions, Transactions of the Laboratory of Volcanology, USSR Academy of Sciences, 9, 1955, (in Russian).

Ponomareva, V. V., Pevzner, M. M., and Melekestsev, I. V.: Large debris avalanches and associated eruptions in the Holocene eruptive history of Shiveluch volcano, Kamchatka, Russia. B. Volcanol, 59, 490-505, 1998, (in Russian).

Ponomareva, V. V., Kyle, P.R., Pevzner, M. M., Sulerzhitsky, L. D., and Hartman, M.: Holocene eruptive history of Shiveluch volcano. Kamchatka Peninsula, in: Volcanism and Tectonics of the Kamchatka Peninsula and Adjacent Arcs, edited by: Eichelberger, J., Gordeev, E., Kasahara, M., Izbekov, P., and Lees, J., American Geophysical Union Geophysical Monograph Series, 172, 263-282, 2007.

Solomina, O., Wiles, G., Shiraiwa, T., and D'Arrigo, R.: Multiproxy records of climate variability for Kamchatka for the past 400 years, Clim. Past, 3, 119-128, 2007, http://www.clim-past.net/3/119/2007/.

Yamaguchi, D. K.: New tree-ring dates for recent eruptions of Mount St. Helens, Quaternary Res., 20, 246-250, 1983.

Yamaguchi, D. K.: Tree-ring evidence for a two-year interval between recent prehistoric explosive eruptions of Mount St. Helens, Geology, 13(8), 554-557, 1985.

Yamaguchi, D. K.: On tree-ring records of volcanic events in Kamchatka and elsewhere, Quaternary Res., 40, 262-263, 1993.

Yamaguchi, D. K. and Hoblitt, R. P.: Tree-ring dating of pre-1980 volcanic flowage deposits at Mount St. Helens, Washington, Geological Society of America Bulletin, 107(9), 1077-1093, 1995.

Zielinski, G. A., Mayewski, P. A., Meeker, L. D., Whitlow, S., Twickler, M. S., Morrison, M., Meese, D. A., Gow, A. J., and Alley, R. B.: Record of Volcanism since 7000 BC from the GISP2 Greenland Ice Core and implications for the Volcano-Climate System, Science, 264, 948-951, 1994. 